\begin{tabular}{cc} 
Coğrafi Bilimler Dergisi & Cogrrafi \\
Bilimler & Dergisi \\
\hline & Turkish Journal of Geographical Sciences
\end{tabular}

\title{
Türkiye'de Evsel Su Tedarik ve Tüketim İstatistiklerinin Değerlendirilmesi
}

Evaluation of Domestic Water Supply and Use Statistics of Turkey

Faize Sarış *a

\begin{tabular}{|c|c|}
\hline Makale Bilgisi & $\ddot{O} z$ \\
\hline Derleme & Hızlı kentleşme, arazi örtüsü değişimi ve doğal afetlerdeki artış tatlı su \\
\hline $\begin{array}{l}\text { DOI: } \\
\text { 10.33688/aucbd.883794 }\end{array}$ & $\begin{array}{l}\text { kaynaklarının miktarı, kalitesi ve erişilebilirliği üzerinde önemli bir baskı } \\
\text { oluşturur. Türkiye'de kentsel nüfus artışına paralel olarak su talebi de }\end{array}$ \\
\hline $\begin{array}{l}\text { Makale Geçmişi: } \\
\text { Geliş: } 20.02 .2021 \\
\text { Kabul: } 23.04 .2021\end{array}$ & $\begin{array}{l}\text { artmaktadır. Ancak, arazi kullanımının ve iklim değişikliklerinin olumsuz } \\
\text { etkileri, ülkenin bazı bölgelerinde su sıkıntısı hatta su kıtlığ ile } \\
\text { sonuçlanmıştır. Bu çalışma, Türkiye'nin son } 25 \text { yıldır evsel su temini ve su }\end{array}$ \\
\hline $\begin{array}{l}\text { Anahtar Kelimeler: } \\
\text { Su Talebi } \\
\text { Evsel Su } \\
\text { Su Kaynakları } \\
\text { Su Güvenliği }\end{array}$ & $\begin{array}{l}\text { kullanım örüntülerinin mekânsal ve zamansal değerlendirmesine } \\
\text { odaklanmaktadır. Ulusal evsel su istatistikleri ve belediye su istatistikleri } \\
\text { TÜIK'ten alındı ve coğrafi perspektifle değerlendirildi. Türkiye'de çekilen su } \\
\text { miktarı artmakta; baraj, kuyu ve pınarlar ana su sağlama kaynaklarını } \\
\text { oluşturmaktadır. Son yıllarda nehirlerden su çekilme oranı artmaktadır. Evsel } \\
\text { kullanım için yüzey sularına bağımlılık, özellikle metropol alanlarda artma } \\
\text { eğilimindedir. Barajların iklim değişikliği ile birlikte değişen yağış desenleri } \\
\text { ve artan buharlaşma bakımından kırılganlığı düşünüldügünde, gelecekte su } \\
\text { güvenliği açısından pek çok risk ortaya çıkabilir. Su ve diğer suyla ilgili } \\
\text { hizmetleri sürdürmek için, belediyeler su kullanım verimliliği yaklaşımlarını } \\
\text { benimsemelidir. }\end{array}$ \\
\hline
\end{tabular}

\begin{tabular}{l} 
Article Info \\
\hline Review Article \\
\hline DOI: \\
10.33688/aucbd.883794 \\
\hline Article History: \\
Received: 20.02 .2021 \\
Accepted: 23.04 .2021 \\
\hline Keywords: \\
Water Demand \\
Domestic Water \\
Water Resources \\
Water Security
\end{tabular}

\begin{abstract}
Rapid urbanisation, land cover change and increasing frequency of natural disaster put significant pressure on quantity, quality and availability of freshwater resources.. Urban population has been increasing in Turkey and parallel to this growth water demand is rising as well. However, negative impacts of land use and climatic changes resulted with water stress even water scarcity for some regions of the country. This study focuses on spatial and temporal evaluation of domestic water supply and water usage patterns of Turkey for the last 25 years. National and municipal domestic water statistics were obtained from TSI and evaluated with a geographical perspective. Water withdrawn has been increasing in Turkey; dams, wells and springs are the main water supply resources. Recently, water withdrawal rate from rivers are increasing. The dependence on surface waters for domestic use tends to increase, especially in metropolitan areas. Considering the fragility of dams in terms of changing rainfall patterns and increased evaporation with climate change, lots of risk might arise in the future regarding water security. To maintain water and other water-related services, municipalities should adopt water-use efficiency approaches.
\end{abstract}

\footnotetext{
*Sorumlu Yazar/Corresponding Author: faizesaris@gmail.com

${ }^{a}$ Çanakkale Onsekiz Mart Üniversitesi, Fen-Edebiyat Fakültesi, Çanakkale, Türkiye. http://orcid.org/xxxx-0002-1721-4959
} 


\section{Giriș}

2000'li yılların başında 6,1 milyar olan Dünya nüfusu, günümüzde 7,7 milyara yaklaşmıştır (WB statistics, 2020). Bu hızlı nüfus artışı, beraberinde pek çok zorluğu da getirmiştir. Hiç şüphesiz artan dünya nüfusunun su, gıda ve enerji talebini karşılamak bu zorlukların başında sayılabilir. Nüfus artışı ve beraberindeki sorunlara, başta iklim değişikliği olmak üzere 21. yüzyıldaki önemli küresel çevresel değişikliklerin yarattığı sorunlar da eklendiğinde; su konusu pek çok boyutuyla özellikle öne çıkar. Su ve suyla ilişikli sistemlerde gözlenen sorunlar, günümüzde küresel ölçekte en kritik konuların başında gelir (Tzanakakis vd., 2020). Çünkü su yalnızca, yerkürede yaşamın devamını sağlayan başat unsur değil; aynı zamanda insan etkinliklerinin tamamında kullanılan birincil maddedir. Artan su su talebinin karşılanması, su kaynaklarının korunması, su stresi, su azlığı ve kıtlığı, su güvenliği, su çatışmaları, su kaynakları yönetimi gibi konular; tekil veya çoklu olarak özellikle iklim değişikliği, kentleşme, arazi örtüsü değişiklikleri ve göç olgusuyla birlikte ele alınan önemli araştırma konularındandır.

Arnell (1999) iklim değişikliğinin su kaynakları üzerindeki baskıları sonucunda 2025 yılına kadar, yaklaşı 8 milyarlık toplam Dünya nüfusundan yaklaşı 5 milyar insanın su stresi yaşayan ülkelerde (mevcut kaynakların \% 20'den fazlasını kullanarak) yaşayacağı projeksiyonunu sunmuştu. 21. yy başlarında yapılan bir diğer modelleme çalışmasında Alcamo vd. (2003) "her zamanki gibi" senaryosu altında, havzalardan su çekiminin gelişmiş ülkelerde azalacağı veya dengeleneceği, gelişmekte olan ülkelerde ise nüfus ve ekonomik büyümenin su talebinin artmasına neden olacağından artacağını belirtmiş̧lerdir. Dünya Su Değerlendirme Programının 2020 raporuna göre su stresi her kıtayı belli ölçülerde etkilemekte, Dünya nüfusunun yarısı bir yıl içinde en az 1 aylık su kıtlığını deneyimlemektedir (WWDR, 2020). Alcamo vd. (2007) tarafından yapılan bir diğer çalışmada ise bu kez 2050 yılı için su kaynaklarının durumu iklim değişikliği senaryolarına göre analiz edilmiştir ve 2050'lerde A2 senaryosu altında şiddetli su stresi kategorisindeki "sıcak nokta" alanları arasında Kuzey ve Güney Afrika'nın çoğu, Orta Doğu, Orta Asya, Güney Asya, Kuzey Çin, ABD'nin batı kıyı bölgeleri ve Kuzeydoğu Latin Amerika öne çıkmıştır. İklim değişikliğinin artan sıcaklıklar ve ekstrem hidrolojik olaylara (sel ve kuraklık) bağlı olarak, miktarda olduğu kadar su kalitesinde de düşüşe neden olabileceği ifade edilmektedir (Delpla vd., 2009; Schlosser vd., 2014).

Su stresi, su arzının miktar, kalite ve erişilebilirlik açısından güvenliğinin olmaması durumunu işaret ederken; su kıtlı̆̆ kurumların düzenli bir su sağlayamaması veya yeterli altyapı eksikliği nedeniyle fiziksel kıtlık veya erişim kıtlığı nedeniyle bulunabilirlikte kıtlık anlamına gelir (WWDR, 2020). Tatlı su kıtlığı, gıda güvenliğini, güvenli içme suyuna erişimi, hijyeni ve halk sağlığını ve çevresel refahı doğrudan etkiler (Taylor, 2009). Eylül 2002'de Johannesburg'da düzenlenen BM Dünya Sürdürülebilir Kalkınma Zirvesinde "Çevresel sürdürülebilirliği sağlamak" için güvenli su kaynaklarına erişim ana koşul olarak belirtilmiştir (Sullivan vd., 2003). Suyun etkin kullanımı diğer sürdürülebilirlik konuları ile birlikte yoksulluğun önüne geçilmesi içinde önem taşır. Çünkü temiz suya erişim yeterli bir yaşam kalitesi için gereklilik olarak kabul edilir.

Küresel ölçekte artan şehirleşme önemli çevresel sorunların oluşmasına neden olmaktadır. Şehirler genişledikçe arazi örtüsündeki değişimler, akarsu havzalarında tarım, orman ve hatta akarsuların kaynak noktası olan dağlık alanlarda degradasyon süreçlerine; buna ek olarak doğal 
afetlerden (erozyon, çölleşme, heyelan ve seller gibi) habitat kaybına kadar oldukça kritik hidromorfolojik ve ekolojik değişikliklere yol açmaktadır. Kıyı bölgelerindeki kentleşme, önemli sulak alanların tahrip olmasının yanı sıra plajlar ve mercan resifleri gibi kritik habitatların yok olmasına neden olabilmektedir (UNEP, 2002). Hızlı ve çoğu zaman planlanmamış kentsel büyüme; içme suyu sağlama ve arıtma, sanitasyon ve atık bertarafı gibi çevresel hizmet kapasitesini zorlayan nüfus talepleriyle de ilişkilidir. Bu tarz kentleşme süreçleri, genellikle önemli bir aşırı talep ve belediye su kaynaklarından aşırı su kullanımına neden olmaktadır (Moorea vd., 2003).

Su güvenliği kavramı 1990'larda ortaya çıktı̆̆ zaman çeşitli şekillerde askeri güvenlik, gıda güvenliği ve (daha nadiren) çevre güvenliği ile bağlantılıydı. 2000 y1lında, İkinci Dünya Su Forumu'nda Küresel Su Ortaklığı, suya erişim ve satın alınabilirliğin yanı sıra insan ihtiyaçları ve ekolojik sağlığı da dikkate alan bütüncül bir su güvenliği tanımı yaptı (Cook ve Bakker, 2012). O zamandan beri, çeşitli bilim insanları ve politika yapıcılar bu terimi farklı anlamlarda kullandı. Bazıları disipline dayalı tanımlar öne sürerken; kimileri ise bütünleştirici, disiplinler arası bir yaklaşım geliştirmiştir. Birleşmiş Milletler Su Programı su güvenliğini; ekosistemleri su kaynaklı kirliliğe karşı korumak, nüfusun sağlık, geçim ve sosyo-ekonomik kalkınmasını sürdürmek, barış ve siyasi istikrar ortamında korumak için "yeterli miktarda ve kabul edilebilir kalitede suya sürdürülebilir erişimi koruma kapasitesi" olarak tanımlamaktadır (Cook, 2016). Su kaynaklarının sürdürülebilirliği, hakkaniyetli tahsisi ve korunması, entegre yönetim ve su yönetişimi çerçevesinde gerçekleşmelidir; ancak bunun uygulanması sorunludur. Dünya genelinde, 2010 y1lında 780 milyondan fazla kişi hala iyileştirilmiş su kaynaklarına erişimden yoksun iken (Hope ve Rouse, 2013) bu rakam günümüzde 1.6 milyara ulaşmıştır (WWDR, 2020). Dünya genelinde politik çatışmalar, sosyo-ekonomik ve ekolojik yıkımlar bu tabloyu giderek kötüleştirmektedir.

Türkiye'de hem hızlı nüfus artışı ve kentleşme, hem de ekonomik büyüme hedefleri su kaynakları üzerindeki baskıları önemli ölçüde artırmaktadır. Zaten tarımsal su tüketiminin, toplam su tüketimi içerisindeki payı oldukça yüksektir. Buna artan içme-kullanma suyu ile enerji ve inşaat alanlarındaki tüketim de eklenenince, ülke genelinde yıllık su tüketimi 2008 y1lında 44 milyar $\mathrm{m}^{3}$ iken, 2020 itibariyle 57 milyar m³'e ulaşmıştır (DSİ, 2020). Türkiye'nin su kaynakları potansiyeli özetlenecek olursa, yıllık ortalama yağış yaklaşık $574 \mathrm{~mm}$ olup, yılda ortalama 450 milyar $\mathrm{m}^{3}$ suya tekabül etmektedir. Günümüz teknik ve ekonomik şartları çerçevesinde, çeşitli maksatlara yönelik olarak tüketilebilecek yerüstü suyu potansiyeli yılda ortalama toplam 94 milyar $\mathrm{m}^{3}$ 'tür, 18 milyar $\mathrm{m}^{3}$ olarak belirlenen yeraltı suyu potansiyeli ile birlikte ülkemizin tüketilebilir yerüstü ve yeraltı su potansiyeli yılda ortalama toplam 112 milyar $\mathrm{m}^{3}$ olup, 57 milyar $\mathrm{m}^{3}$ 'ü kullanılmaktadır. 57 milyar $\mathrm{m}^{3}$ 'lük suyun \%77'si tarımda, \%23'ü ise içme-kullanma ve sanayi suyu olarak tüketilir (DSİ, 2020).

Kişi başına düşen yıllık su tüketimi için Falkenmark tarafından geliştirilen ve yaygın olarak kabul edilen göstergeye göre, yıllık 1000-1700 m³ arası miktar su stresi aralığı olarak kabul edilmektedir (Falkenmark ve Widstrand, 1992). Türkiye'de kişi başına düşen kullanılabilir yıllık su miktarı 2000 
yılında $1652 \mathrm{~m}^{3}, 2009$ yılında $1544 \mathrm{~m}^{3}, 2020$ y1lında ise $1346 \mathrm{~m}^{3}$ ile giderek azalmakta ve bu rakamlar ile Türkiye su stresi yaşayan ülkeler kategorisinde konumlanmaktadır.

Türkiye için su kaynaklarının kullanımı ve su sorunları üzerine gerçekleştirilen çalışmalarda ağıllıklı olarak tarımsal sulama, hidroelektrik ve sınır aşan sular konularına yoğunlaşıldığı gözlenir. Son yıllardaki çalışmalara bakıldığında, Türkiye için özellikle 2007-2011 yılları arasında Avrupa Birliği Su Çerçeve Direktifi uyum çalışmaları kapsamında yürütülen etkinlikleri değerlendiren pek çok çalışmaya rastlanır (Aküzüm vd., 2010; Bulut ve Birben, 2019; Erol, 2006; Garipağaoğlu, 2012; Meriç, 2004; Öztürk vd., 2014). Bu çalışmalarda Türkiye'nin havza yönetimi açısından zayıf-güçlü yönleri, teknik ve kurumsal alt yapısı değerlendirilmiştir. Bunlara ek olarak, iklim değişikliğinin Türkiye'de özellikle yüzey suları bakımından yaratabileceği olumsuz etkilerin genel olarak değerlendirildiği çalışmalar mevcuttur (Kanber vd., 2010; Karaman ve Gökalp, 2010; K1lıç, 2008; Şen, 2005; Tuğaç, 2014). Bu çalışmalarda ifade edilen olumsuz etkiler; García-Ruiz vd. (2011) tarafından Akdeniz havzası ülkeleri için ortaya konulduğu gibi nehir rejimi özelliklerindeki değişiklikler, ilkbaharda eriyen karlardan kaynaklanan yüksek akımlarda daha erken bir düşüş, yazın düşük akımının yoğunlaşması ve kışın daha düzensiz akımlar; tarımsal ve evsel su talebini karşılamak için barajlardan daha yüksek su talebi neticesinde rezervuar kapasitelerinde düşüş, dağlık bölgelerdeki kar birikimi ve kar erimesi süreçlerinin etkisinin azalması nedeniyle artan su kaynağı belirsizliği olarak özetlenebilir.

$\mathrm{Bu}$ çalışma, küresel ölçekte bir problem olarak öne çıkan su güvenliğine, Türkiye özelinde, içme-kullanma suyu perspektifinden güncel bir değerlendirme sunmak için hazırlandı. Literatür taraması, sayısal verilere dayalı detaylı bir alansal ve zamansal çözümlemenin eksikliğini göstermektedir. Buradan hareketle, bu çalışmada; Türkiye'de son 25 yıllık süreçte içme suyu sağlama ve tüketim durumunun zamansal değişimini vermek, yüzey ve yeraltı su kaynakları üzerindeki alansal baskılara işaret etmek ve Türkiye için evsel su tüketiminin durumunu tartışmak hedeflendi. Illler bazında yapılan karşılaştırmalarla, içme suyu sağlama ve tüketimindeki alansal farklılaşmalar, fiziki ve sosyal nedenleri ve sıcak noktaları ortaya koyacak şekilde değerlendirilmeye çalışıldı.

\section{Materyal ve Yöntem}

Türkiye'de iller düzeyinde içme suyu sağlama kaynăğ/miktarı ve tüketim paternlerini ele alan çalışmada veri olarak Türkiye İstatistik Kurumu'nun sağladığı su istatistikleri kullanıldı (TUİK, 2020). Çalışma kapsamında değerlendirilen veriler aşağıda listelendi:

Zamansal değerlendirme için kullanılan ülke istatistikleri (1994-2018 yılları arasında):

1. İçme ve kullanma suyu şebekesi ile hizmet verilen nüfusun toplam belediye nüfusuna oranı (\%)

2. İçme ve kullanma suyu şebekesi için çekilen toplam su miktarı (bin $\left.\mathrm{m}^{3} / \mathrm{y} 11\right)$

3. Çekim kaynağına göre:

- Kaynak (Pinar) $\left(\right.$ Bin $\left.\mathrm{m}^{3}\right)$

- Göl / gölet / deniz $\left(\right.$ Bin $\left.\mathrm{m}^{3}\right)$

- Akarsu $\left(\right.$ Bin $\left.\mathrm{m}^{3}\right)$

- $\operatorname{Baraj}\left(\right.$ Bin $\left.^{3}\right)$

- Kuyu $\left(\right.$ Bin $\left.\mathrm{m}^{3}\right)$ 
4. İçme ve kullanma suyu şebekesi için çekilen yüzey suyu miktarı (bin $\left.\mathrm{m}^{3} / \mathrm{y} 11\right)$

5. İçme ve kullanma suyu şebekesi için çekilen yeraltı suyu miktarı (bin $\mathrm{m}^{3} / \mathrm{y} 1 \mathrm{l}$ )

6. Kişi başı çekilen günlük su miktarı (litre/kişi-gün)

Alansal değerlendirme için il düzeyinde kullanılan 2018 yılı istatistikleri:

1. Çekilen su miktarı $\left(\right.$ Bin $\left.\mathrm{m}^{3}\right)$

2. Çekim kaynağına göre dağılış:

- Kaynak (Pınar) (Bin $\left.\mathrm{m}^{3}\right)$

- Göl / gölet / deniz $\left(\operatorname{Bin} \mathrm{m}^{3}\right)$

- Akarsu (Bin $\left.\mathrm{m}^{3}\right)$

- Baraj $\left({\left.\text { Bin } \mathrm{m}^{3}\right)}^{3}\right.$

- Kuyu (Bin $\left.\mathrm{m}^{3}\right)$

3. Kişi başı çekilen günlük ortalama su miktarı (Litre/kişi/gün)

$\mathrm{Su}$ istatistikleri grafik ve haritalar aracılığıyla görselleştirilip; gözlenen zamansal ve alansal değişkenlikler, çeşitli dinamikler ve önceki çalışmalar göz önünde bulundurularak yorumlandı.

\section{Bulgular}

\subsection{4-2018 Yılları Arasındaki İçme - Kullanma Suyu İstatistiklerinin Analizi}

Türkiye'de 2018 y1lı itibariyle içme ve kullanma suyu şebekesi ile hizmet verilen nüfusun toplam belediye nüfusuna oran1 \%99 düzeyindedir, bu oran 1994'de \%88'di (TÜİK, 2020). İçme ve kullanma suyu şebekesi için çekilen su miktarı 25 yılda iki katına çıkarak çok yüksek bir artış göstermesine rağmen; kişi başı çekilen günlük su miktarında ise azalış dikkati çeker (Şekil 1). İçme ve kullanma suyu şebekesi için çekilen su miktarı 1994 yılında 3,24 milyar m'ten 2006 y1lında 5,16 milyar m'e ulaşmış; 2008 yılında tekrardan 5 milyar $\mathrm{m}^{3}$ 'ü altına gerilese de, 2014 itibariyle tekrar 5 milyar $\mathrm{m}^{3}$ '̈̈ geçmiş ve 2018 yılında yaklaşık 6.2 milyar $\mathrm{m}^{3}$ olmuştur. Türkiye nüfusu son 25 yıllık dönemde 60 milyondan yaklaşı 80 milyona ulaşmış; bu artan nüfusun ihtiyaçlarını karşılamak üzere tüm sektörlerde su talebi artmıştır. Aynı zamanda kentsel yaşam standartlarının yükselmiş olmasının da daha fazla su tüketimine yol açtığı bilinmektedir. İçme ve kullanma suyu amaçlı şebeke için su çekimi artarken; kişi başına düşen günlük su miktarı ülke ortalaması bakımından giderek azalmaktadır (Şekil 1). Kişi başına düşen günlük su tüketiminde 2014 yılında gözlenen ani düşüş; 2014 y1lında 6360 Sayılı On Dört İlde Büyükşehir Belediyesi Ve Yirmi Yedi İlçe Kurulması İle Bazı Kanun Ve Kanun Hükmünde Kararnamelerde Değişiklik Yapılmasına Dair Kanun hükümlerinin uygulamaya konulması ile içme-kullanma suyu şebekesi ile hizmet verilen nüfus miktarının yaklaşık 8 milyon artış göstermesi (TÜiK, 2020); buna karşın şebekeye alınan su miktarında eş zamanlı bir artış sağlanamaması ile ilgili olabilir. Bunun yanı sıra, 2014 yılı kuraklık açısından da ekstrem bir yıl olarak kayıtlara geçmiştir (MGM, 2021).

Yağışlarda (özellikle kar yağışı) azalma ve rekor sıcaklıklar gibi klimatolojik ekstremler günümüzde daha çok gözlenmektedir. Bu durum, suyun verimli kullanımını zorunlu hale getirmektedir. Hidrolojik sistemden, emniyetli rezerv gözetilerek su çekilmelidir. Dolayısıyla, su kaynakları mühendislik olarak barajlarla vs. geliştirilse de, suyun farklı rezervuarlarda yağışlarla yenilenme süresi göz önünde bulundurularak su çekimi yapılır. Eğer herhangi bir bölgede su kaynaklarının yenilenme 
hızı düşükse, su tüketimi kontrol altına alınmalıdır. Öte yandan, kişi başına düşen su miktarı aynı zamanda bir gelişmişlik göstergesidir. Ancak bu sürekli artan bir su tüketimi anlamına gelmez. Kişi başına düşen su tüketim miktarı, su stresine girmeden ve suyun yenilenme süresini de gözeterek etkin su kullanımı yaklaşımları ile kontrol edilmelidir.

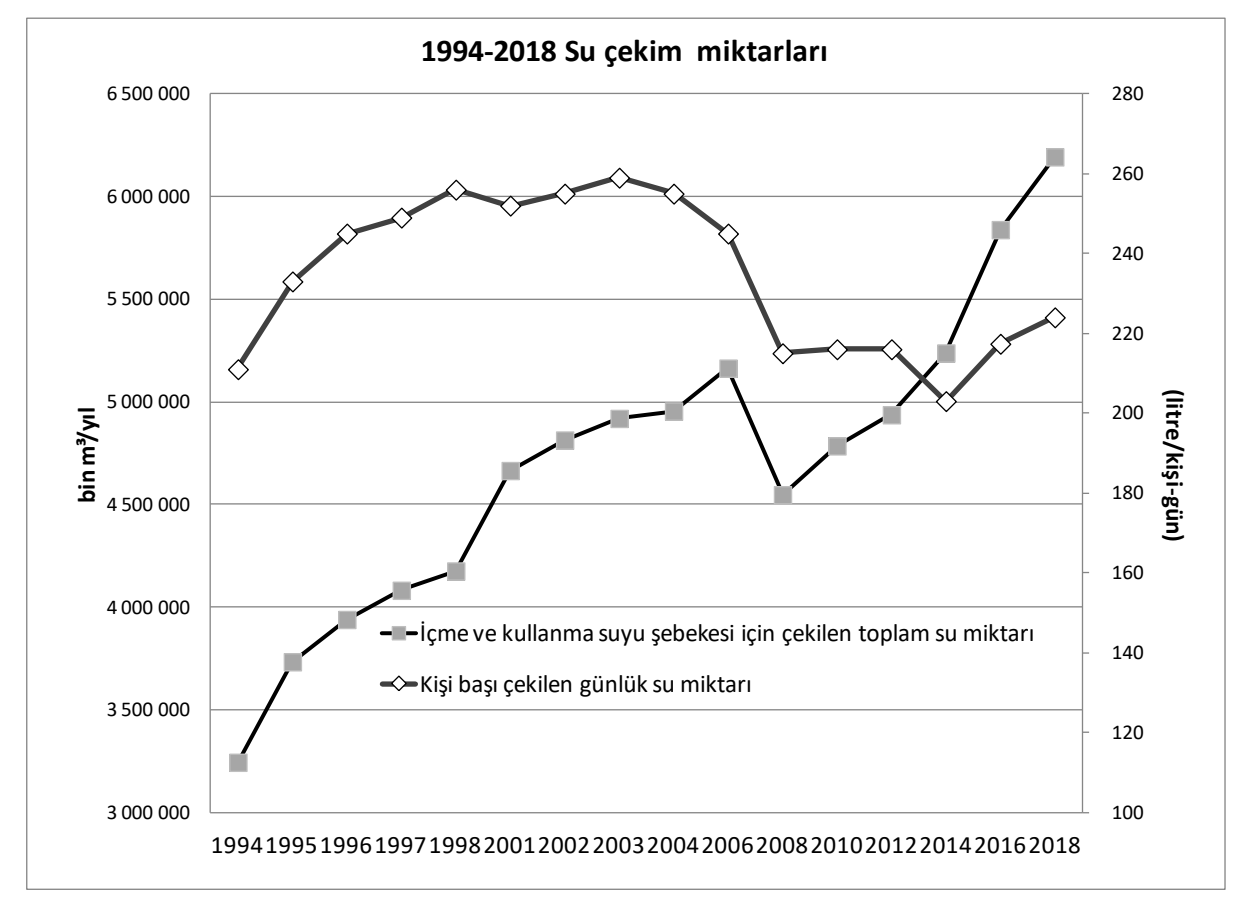

Şekil 1. Türkiye genelinde içme ve kullanma suyu şebekesi için çekilen toplam su miktarı ve kişi başı çekilen günlük su miktarı (Veri kaynağı: TÜİK, 2020).

Evsel su kullanımı için çekilen su kaynakları 5 kategoride değerlendirilir: Kaynak (karışıklık olmaması adına buradan itibaren pınar kelimesi de kullanılacaktır), kuyu, baraj, akarsu, göl/gölet-deniz. Türkiye'de hem yeraltı hem de yüzey su kaynakları son 25 yılda yoğun oranda kullanılmaya başlanmıştır. Şekil 2'de görüldügü gibi, ülke genelinde 2008 yılına kadar kuyu ve pınarlar ağırlıklı olarak evsel su çekimi için değerlendirilirken, 2008 yılından günümüze gelene dek yüzey suları (baraj, göl/gölet ve akarsu) kullanımı artmıştır. Bu durumun en önemli nedenlerinden biri 2000'li yıllardan itibaren artan baraj projeleridir. Türkiye'de FAO 2008 su istatistiklerine göre 584 adet baraj bulunur (FAO, 2008). Bu barajların Doğu, Güneydoğu ve Akdeniz bölgesinde yer alanlarının ana inşa amacı hidroelektrik iken, İç Anadolu, Ege ve Marmara'da ise ağırlıklı olarak içme suyu temini amaçlı baraj/gölet yapımı yaygındır. FAO 2008 su istatistiklerine göre Türkiye'de içme suyu temini için yararlanılan baraj/gölet 
sayısı 77'dir. Güncel durum için DSİ 2019 y1lı istatistiklerine bakıldığında 97'e ulaştığı görülebilir (DSİ, 2019).

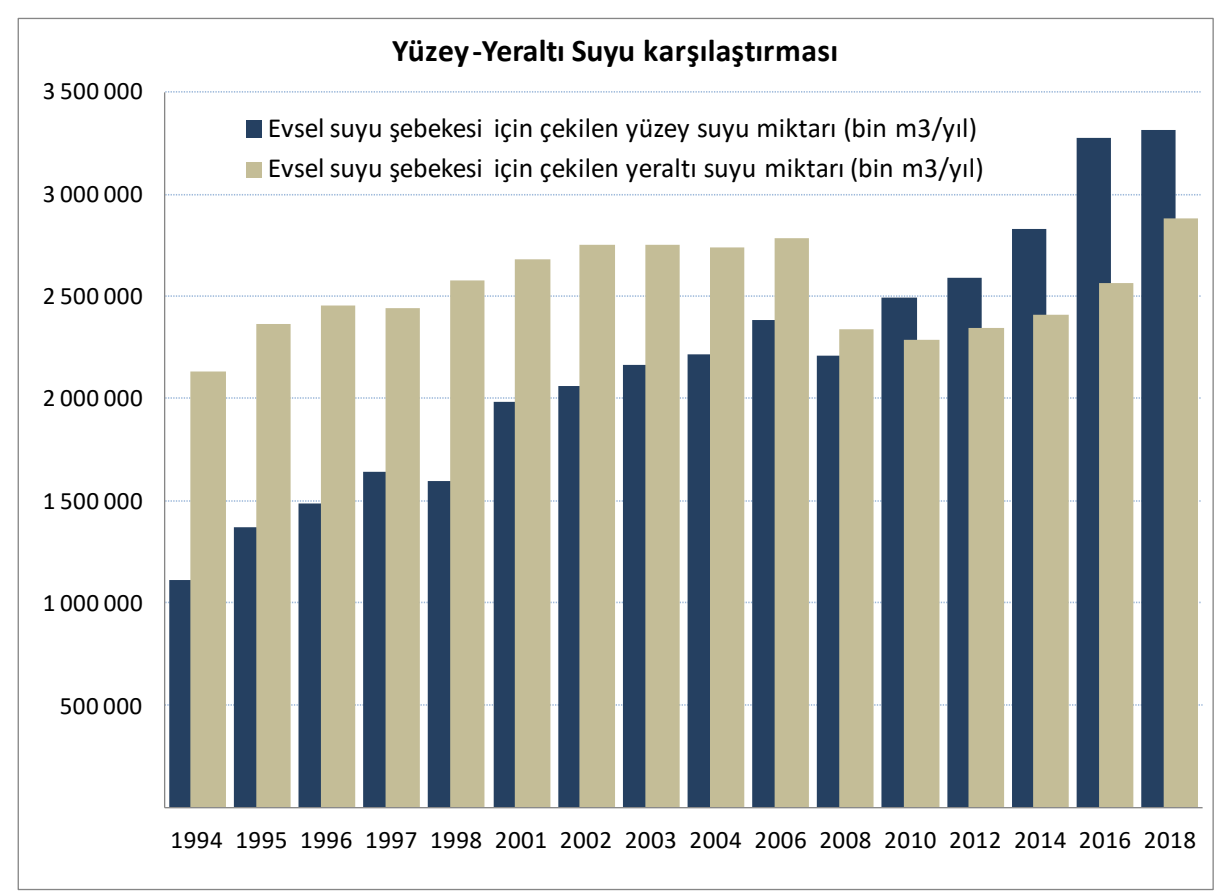

Şekil 2. Türkiye genelinde içme-kullanma suyu şebekesi için çekilen yüzey ve yeraltı suyuna miktarları (Veri kaynă̆ı: TÜİ, 2020).

Türkiye genelinde, evsel su tüketimi için çekilen su miktarlarının farklı kaynaklara göre oranı ve yıllar içindeki değişimi Şekil 3'te verildi. 1994-2000 arasında yeraltı suyunun yoğun kullanıldığı ve kuyu suları ile pınar sularından daha fazla çekim yapıldığı açıkça görülür. 2000'li yıllarla birlikte, artan nüfus ve kentleşme oranına paralel olarak barajlardan su çekiminin önemli ölçüde arttığı ortadadır. 


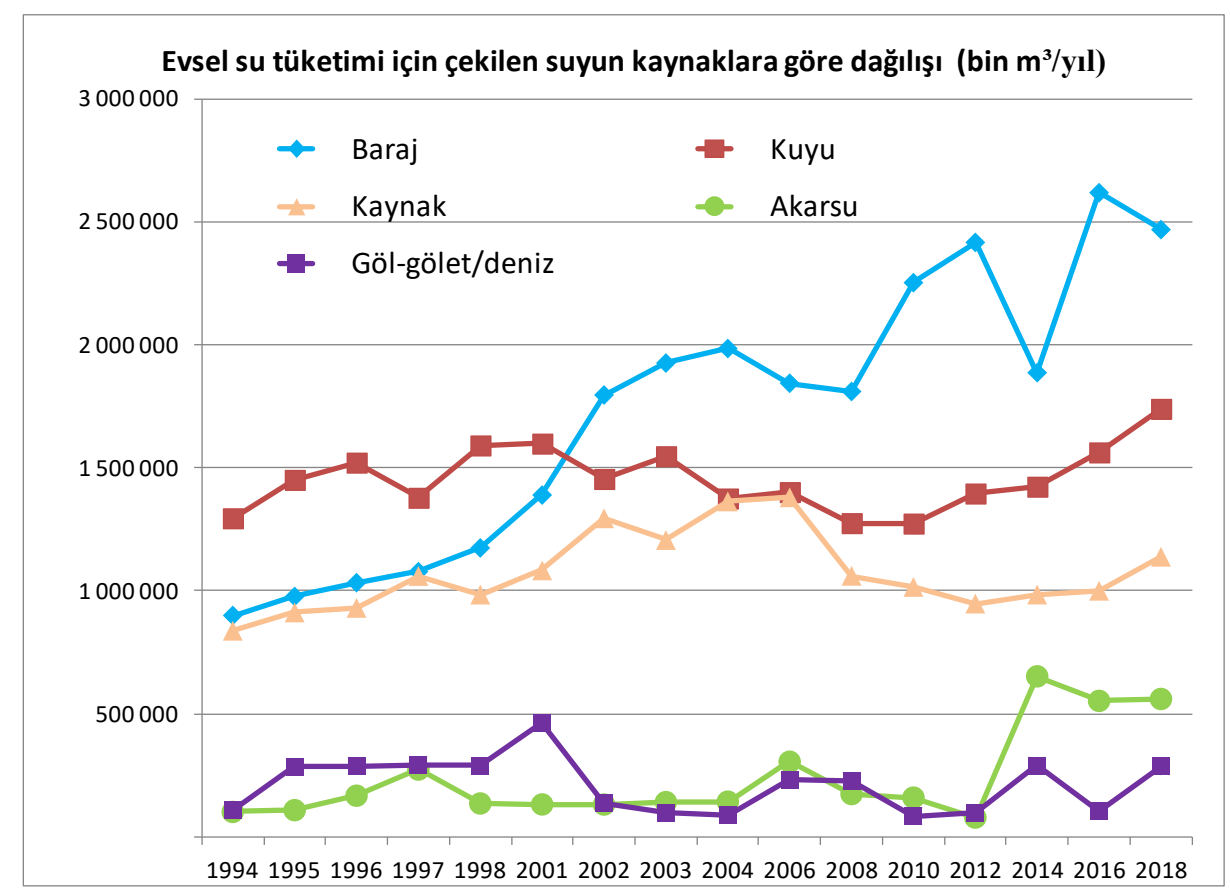

Şekil 3. Türkiye genelinde evsel su tüketimi için çekilen suyun kaynaklara göre dağıllışı (Veri kaynağı: TÜİK, 2020).

2014 yılındaki ani düşüş, yukarıda ifade edildiği gibi kuraklıkla ve barajlardaki su potansiyelinin düşüşü ile ilişkilendirilebilir. Barajlarla birlikte, son yıllarda akarsulardan su çekimindeki artış da dikkat çekicidir. Kuyulardan su çekimi son 25 yılda hemen hemen aynı düzeyde seyrederken, 2008 yılından sonra kaynak (pınar) sularında azalma olduğu gözlenmektedir. Burada kaynak sularının kar yağışlarıyla yeterince beslenememesi önemli bir faktör olarak göz önünde bulundurulabilir.

Şekil 4'te belediyelerce içme-kullanma suyu şebekesine alınan suyun kaynaklara göre oransal dağılışı hesaplandı, onar yıllık değişiklikleri izlemek amacıyla 1994, 2004 ve 2014 yıllarındaki dağılış grafiklendirildi. Buna göre 1994'te Türkiye'de belediyelerce sağlanan evsel su hizmetlerinin \%94'ünü, \%39 ile kuyular, \%29 ile barajlar ve \%26 oranında kaynak suları oluşturmaktaydı. 2004 yılında bu üç kaynak \%95 oranında en önemli üç kaynak olmayı sürdürürken, barajların oranındaki artış (\% 11 artarak \%40'a ulaştı) dikkat çekicidir. 2014 yılında ise barajların oranı \%36 ile en yüksek olup, akarsu (\%12) ve göl/gölet/deniz (\%6) kaynaklarının kullanımındaki \%13'lük artış dikkat çekidir. Bu artışla birlikte yüzey sularının toplam içindeki payı 2014 yılı için \%54'e yükselmiş 2018'e kadar bu oranda devam etmiştir (TÜIK, 2020). 2014 yılında pınar sularında azalma söz konusu oldu. 


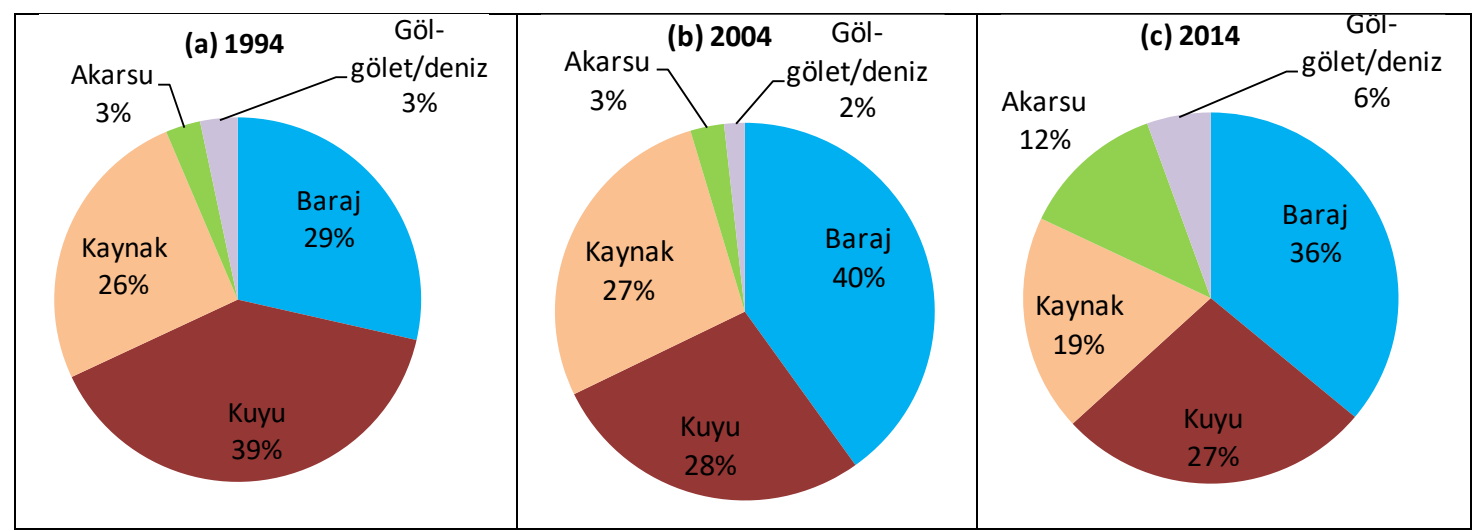

Şekil 4. Türkiye genelinde 1994, 2004 ve 2014 yıllarında evsel su çekim kaynaklarının oransal dağılımı (Ham Veri kaynağı: TÜİK, 2020).

\subsection{Y1lı İstatistiklerine Göre İl Bazında Değerlendirme}

Alansal değerlendirmeler için 2018 yılı verileri haritalandı. İlk olarak Şekil 5'te illere göre 2018 yılında (a) belediyelerce çekilen su miktarı, (b) kişi başı çekilen günlük ortalama su miktarları gösterildi. Çekilen su bakımından Türkiye'nin en kalabalık 3 metropol şehri olan İstanbul, Ankara ve İzmir'de en yüksek tutarlar görülür. Nüfus sıralamasına göre 4. büyük il olan Bursa yerine, Antalya su çekiminde 3 büyük metropolden sonra gelir. Özellikle yaz aylarında artan sıcaklıkla birlikte daha fazla su tüketilmesi ve turizm etkinliklerine bağlı olarak nüfus artışı Antalya'da su tüketiminin artması ile ilişkilendirilebilir. Genel olarak Türkiye'nin batısında nüfus oranı daha yüksek olduğundan evsel su kullanımı için çekilen su miktarı da daha fazladır. En düşük oranlara ise İç Anadolu (Çankırı, Kırıkkale, Kırşehir, Nevşehir, Aksaray ve Niğde) ile Batı ve Doğu Karadeniz illerinde rastlanır. Bu iller Türkiye'de nüfusun az olduğu yerlerdir (Şekil 5a).

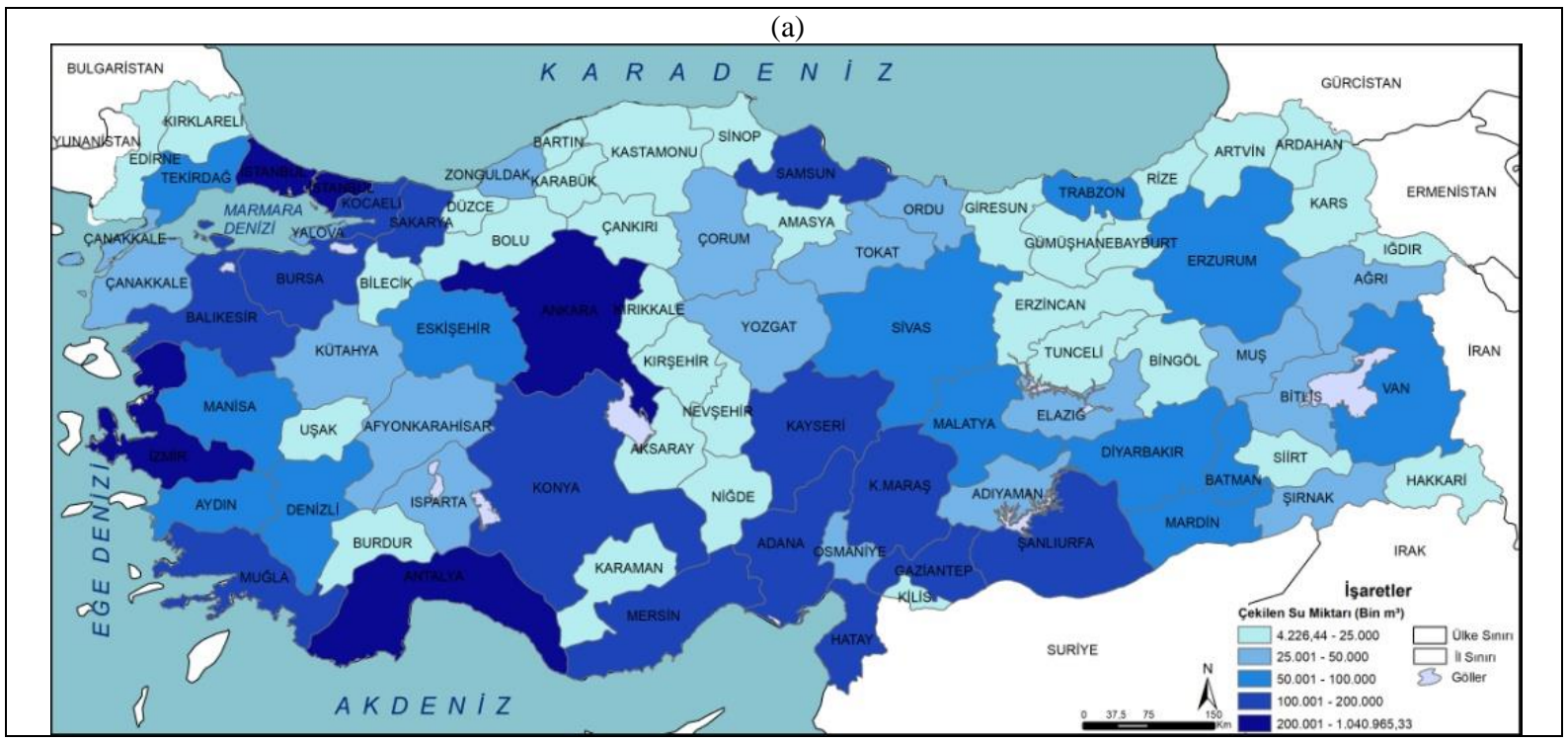




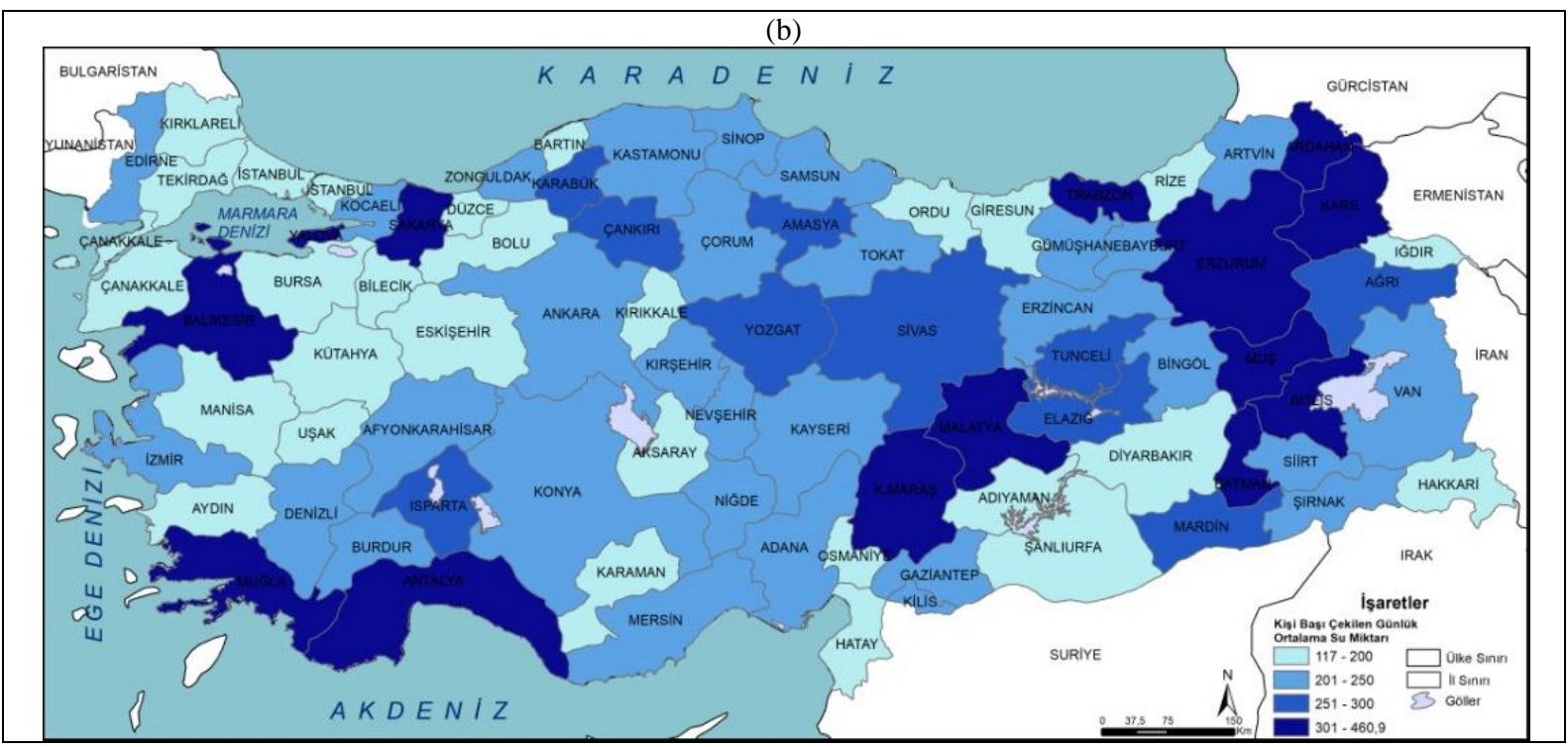

Şekil 5. İllere göre 2018 yılında (a) belediyelerce çekilen su miktarı, (b) kişi başı çekilen günlük ortalama su miktarı (Veri Kaynağı, TÜİK, 2020).

Şekil 5b'de kişi başı çekilen günlük ortalama su miktarında ise farklı bir alansal patern vardır. 2018 yılında kişi başına çekilen su miktarı genel olarak doğu ve güneydoğuda daha yüksek olmakla birlikte, detaylı olarak irdelenecek olursa Ardahan, Kars, Erzurum, Muş, Bitlis, Batman, Malatya, Kahramanmaraş'ta en yüksektir. Ayrıca Karadeniz bölgesinde Trabzon, batıda Marmara bölgesinde Balıkesir, Sakarya, Yalova ve güneyde Akdeniz bölgesinde ise Muğla ve Antalya'da oldukça yüksek tutarlar kaydedilmiştir. Doğu illerinde nüfusun düşük, su kaynaklarının bol olması söz konusudur. Batı ve güneydeki illerin kişi başına çekilen günlük ortalama su miktarındaki artış ise bu illerde (Yalova hariç) su kaynaklarının zenginliği (hem yüzey, hem yeraltı) olduğu ifade edilebilir. Yalova'daki yüksek tutarlar ise Marmara bölgesi içerisinde en az nüfusa sahip il olması ile açıklanabilir. Kişi başına çekilen günlük ortalama su tutarının en az olduğu alanlar bölgesel olarak (yukarıda ifade edilen istisnalar hariç) Marmara bölgesidir. Marmara bölgesi ülkenin en yoğun nüfuslanmış bölgesi olmakla birlikte su kaynakları açısından zengin değildir ve kişi başına çekilen su miktarı giderek azalmaktadır. Marmara bölgesi dışında, İçbatı Anadolu, Orta Anadolu ve Güneydoğu Anadolu'daki bazı illerde kişi başına çekilen günlük ortalama su miktarı düşüktür.

Belediyelerce dağıtılan evsel suyun hangi kaynaklardan çekildiği, her il için yüzdelik olarak TÜIK verilerinden hesaplandı ve haritalandı (Şekil 6 ve 7). Şekil 6'da kuyu suları ve pınarlardan; Şekil 7 ise yüzey suları olan baraj ve akarsulardaki çekim oranının illere göre dağılışı gösterildi. $\mathrm{Bu}$ hartalardaki yüzdelikler, her ilin kendi içinde içme-kullanma suyunu temini hangi kaynaktan ne oranda sağladığını gösterir. Yüzey suyu olarak göl/gölet/deniz kategorisi de bulunmaktadır. Ancak çekim miktarı diğerlerine göre daha düşük olduğu ve belli illerde sınırlandırıldığ i için görsel olarak çalışmaya alınmamış olsa da, metin içerisinde yüzey suları değerlendirilirken değinildi.

2018 yılında belediyeler tarafından evsel amaçlı su tüketiminin çekim kaynaklarına bakıldığında kuyu kategorisinde en fazla su çekiminin; Marmara bölgesinde Tekirdağ ve Kırklareli, Ege'de İzmir ve Manisa, Batı Akdeniz'de Antalya ve Burdur ile İç Anadolu bölgesinin güney ve doğu kesimlerindeki 
illerde \% 80-100 oranında gerçekleştiği görülebilir (Şekil 6a). İç Anadolu bölgesinde Konya başta olmak üzere; Karaman, Niğde ve Nevşehir gibi pek çok ilin yüzey su kaynakları sınırlı olduğundan su talebinin yeraltı suyunda karşılandığı bilinmektedir. Doğu Anadolu'da ise Gümüşhane, Elazığ, Batman ve Iğdır \%80-100 aralığında su çekimi sınıfındadır. \%61-80 bandında alansal olarak bakıldığında yer yer öne çıkan iller vardır: Sivas, Erzincan, Amasya, Hatay, Kilis gibi. Türkiye'nin kuzey doğusu ve kuzey batısındaki illerde ve GAP (Güneydoğu Anadolu Projesi) bölgesinde kuyu suyu çekim oranları \%20'den azdır. Bölgesel olarak değerlendirilecek olursa en fazla yeraltı suyu bağımlılığı Batı Akdeniz ve İç Anadolu'da gözlenir.

Şekil 6b'de ise Kaynak (pınar) suları açısından dağılış verildi. Doğu illerinde pınarlardan su çekim oranı daha yüksektir. \%80'den fazla oranla öne çıkan iller: Malatya, Adıyaman, Bingöl, Bayburt Ardahan. Doğu Anadolu'nun büyük bölümünde pınarlardan su çekim oranı \%20-80 arasında değişir. Batıda ise Bilecik ve Karabük \%80'den fazla çekim oranına sahip iller iken, Batı Karadeniz ve İç Batı Anadolu'daki iller de kaynak sulardan çekim oranları \%20-60 oranında değişir. Pınarlardan temin oranının yüksek olduğu iller daha çok dağlık ve tektonik alanları temsil etmektedir. İç Anadolu, Marmara ve Güneydoğu Anadolu illerinde oranlar en düşüktür.

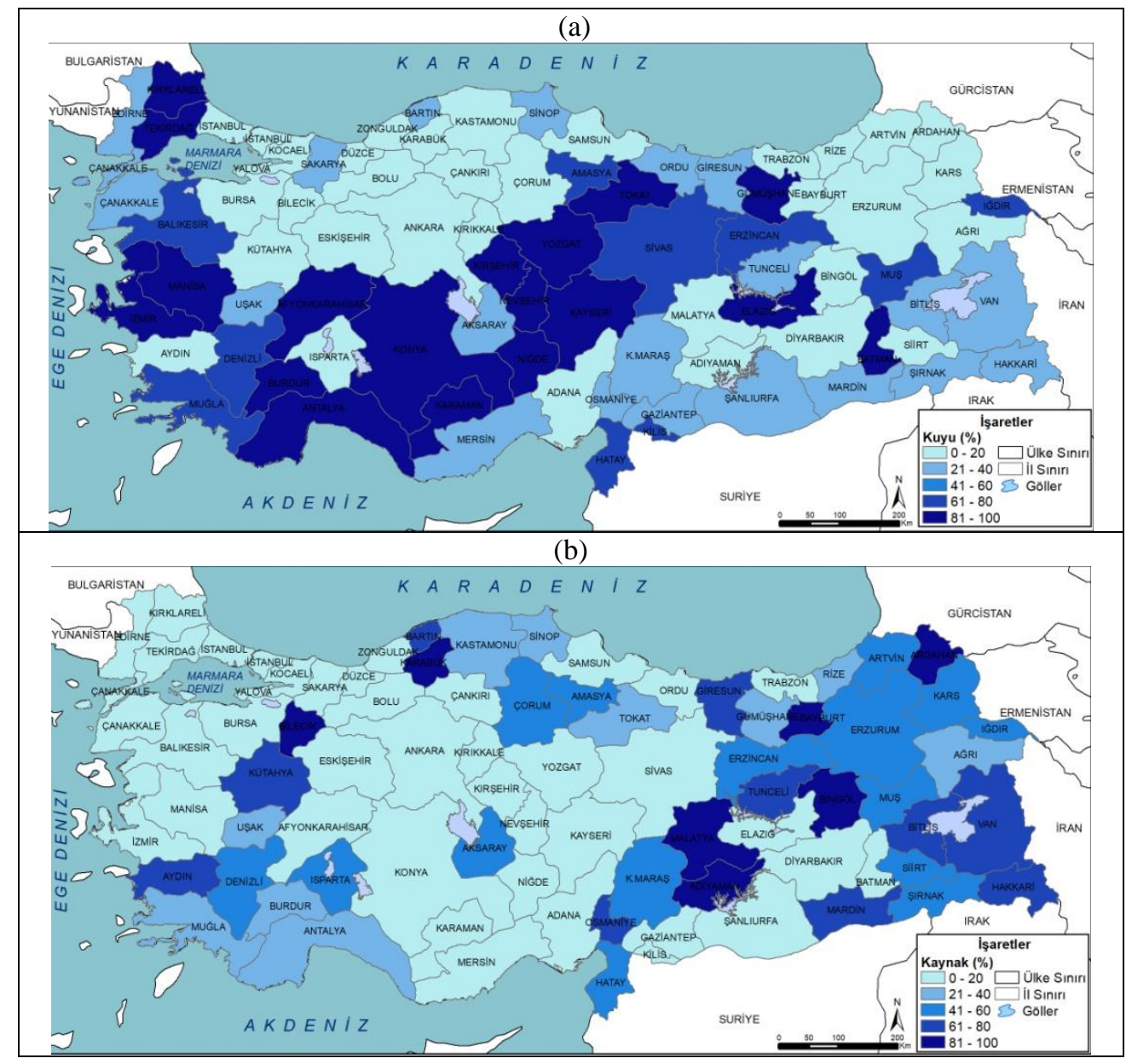

Şekil 6. 2008 yılı illere göre (a) kuyu ve (b) kaynak sularında su çekimi oranı (Ham Veri kaynăğ: TÜİK, 2020). 
Yüzey suları açısından en fazla kullanılan su deposu barajlardır. Şekil 7a'da illerin toplam evsel su tüketimi içerisinde baraj suları çekim oranları gösterilmiştir. Bu haritaya göre batıda Marmara bölgesinde Kocaeli ve Yalova \% 80-100, Bursa, Çanakkale ve Edirne \% 60-80, İstanbul ise \% 40-60 aralığında baraj sularına bağımlıdır. \% 60'dan daha yüksek çekim oranıyla dikkat çeken diğer bölgeler başta Ankara ve Eskişehir olmak üzere İç Anadolu, Batı Karadeniz ve Akdeniz ile GAP bölgesi illeridir (Diyarbakır, Şanlıurfa, Gaziantep). Akdeniz'de de Seyhan ve Göksu gibi iki önemli akarsu havzası ve baraj alanlarının olduğu Adana ve Mersin illerinde evsel su tüketimi yüksek oranda barajlardan temin edilmektedir. Karadeniz ise yüksek yüzdelik oranı ile Samsun ve Trabzon dikkati çeker. Ege, İç Anadolu ve Doğu Anadolu'da ise barajlara bağımlılık oldukça düşüktür.

Akarsu ve göl/gölet/deniz kaynaklarından su çekimi Türkiye'de oldukça düşüktür. Hidrolojik döngü içerisinde suyun rezervuarda kalış süresi bakımından 6-12 ay ile akarsular su yenilenme hızının yüksek ama aynı oranda yıl içinde su miktarındaki değişkenliklerin de fazla olduğu bir kaynaktır. Ayrıca, bir havza içerisinde akış gösteren bir akarsu, diğer ekosistemlerle ilişki içerisinde olduğundan, ekolojik yaklaşım çerçevesinde su akışına müdahale edilmemesi daha uygundur. Bu nedenle eğer alternatif bir kaynak varsa akarsular doğrudan evsel su tüketimi için değerlendirilmez. Zaten potansiyeli yüksek olan akarsular için üzerine baraj inşa edilerek hem hidroelektrik hem de bölgesine göre değişmekle birlikte tarımsal sulama ve/veya evsel su kullanımında yararlanılır. Şekil 7'b'ye bakıldığında, Türkiye'de iller bazında çok az ilde akarsudan doğrudan su çekimi yapıldığı görülür. Ülkenin büyük bir bölümünde bu oran \%20'den az, hatta sıfırdır. Su çekim oranının en fazla olduğu iller ağırlıklı olarak kuzeyde yer alır ve sirasıyla Düzce, Rize, Artvin, İstanbul, Ordu ve Trabzon'dur. Dicle havzasında yer alan Siirt'de \% 60'a yaklaşan oranıyla akarsudan su çekim oranının yüksek olduğu illerdendir. Türkiye'nin kuzeyinde, Karadeniz kıyı kuşă̆ındaki kentlerde yüzey su drenajı zengin olduğundan, yüzey sularından yararlanma yüksektir. Burada İstanbul özelindeki dış kaynaklardan su transferi durumundan bahsetmek gereklidir. Batı Karadeniz bölümünde yer alan Melen Çayı havzasından "Büyük Melen Projesi" kapsamında su sağlanmaktadır. Aynı zamanda, Trakya bölümünde yer alan Istranca derelerinden de su transferi söz konusudur.

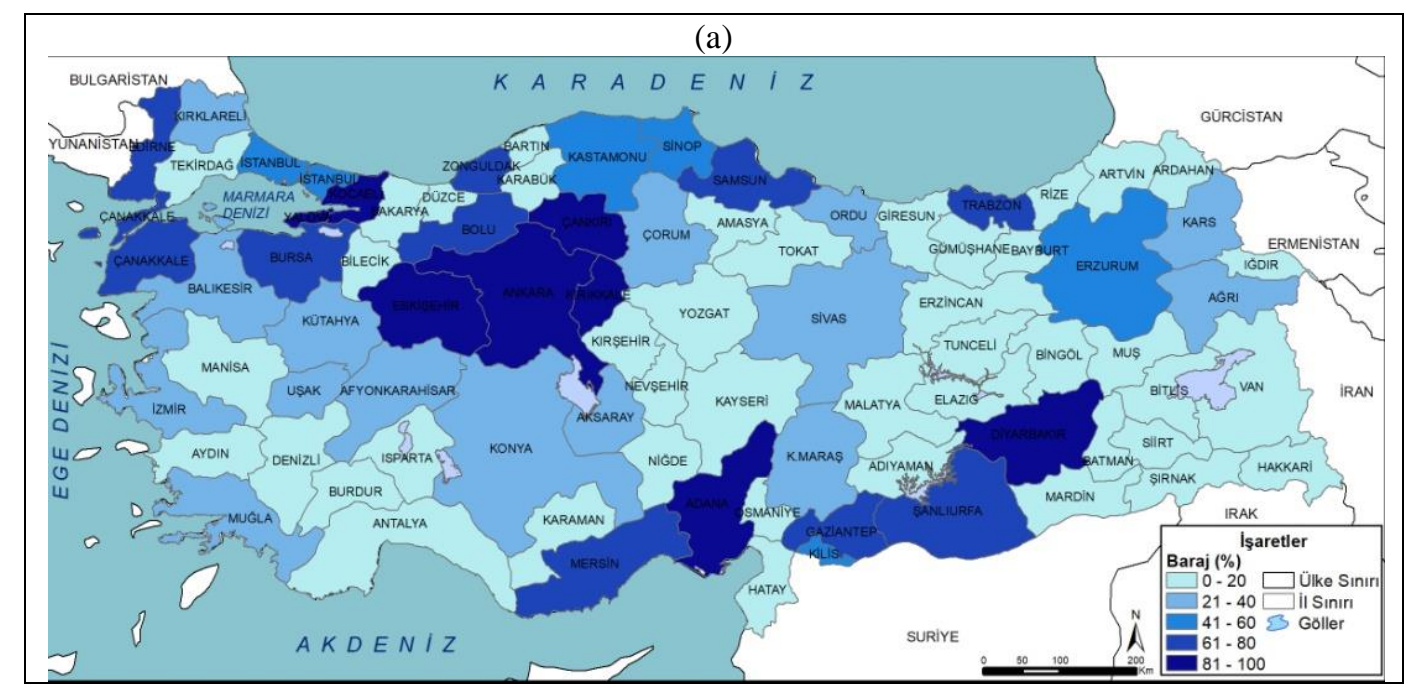




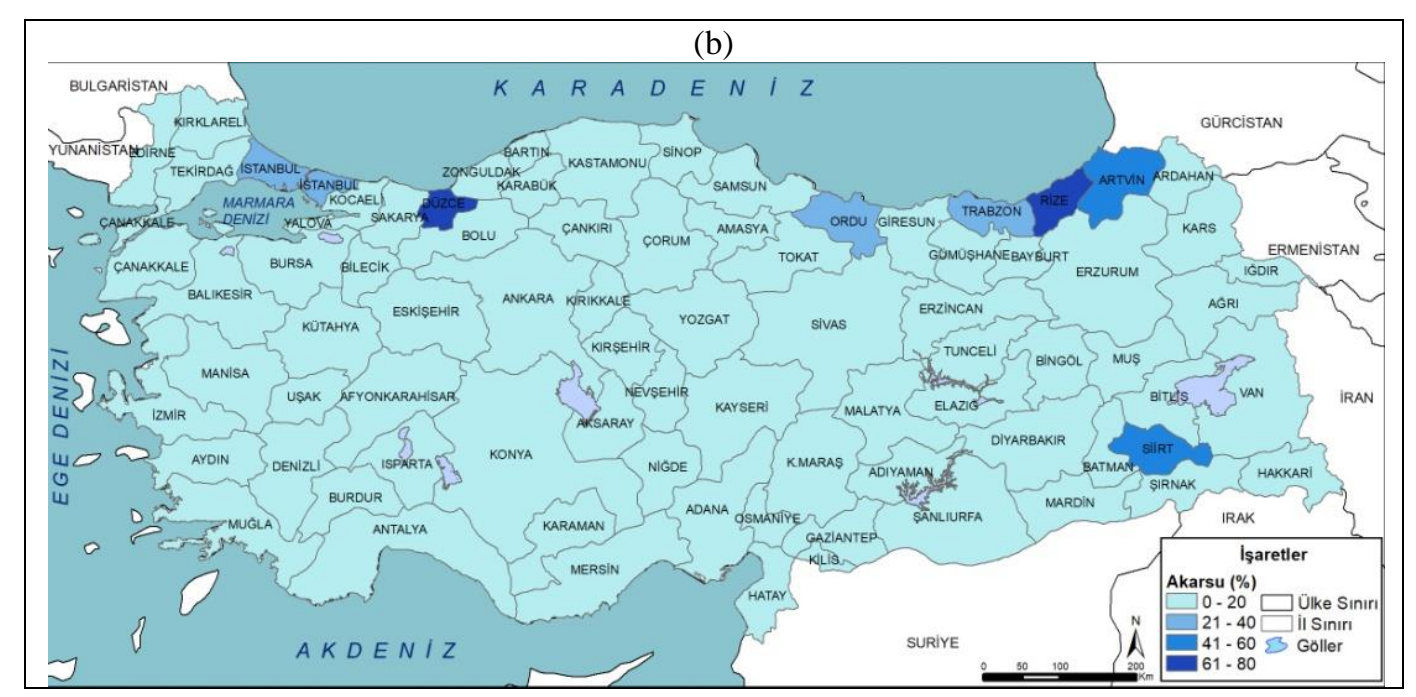

Şekil 7. 2008 yılı illere göre (a) baraj ve (b) akarsulardan su çekimi oranı (Ham Veri kaynağı: TÜİK, 2020).

Belli başlı illerle sınırlı bir alansal patern, göl/gölet/deniz kaynaklarından su çekimi için de söz konusudur. Ülkenin çok önemli bir bölümünde oran sıfırdır; en fazla Sakarya (\% 59,7); Isparta (\% 34), İstanbul $(\% 16,4)$ da gözlenir. Bu durum, bu illerde yer alan tatlı su gölleri ile ilgilidir. Sakarya ili için Sapanca, Isparta için Gölcük ve İstanbul için ise Büyük Çekmece ve Terkos göllerinden su çekimi yapilmaktadır.

2018 yılı istatistiklerine göre, evsel su tüketiminin su çekim kaynağına oranlarının il bazında değerlendirilmesi sonucunda, Türkiye'de yüzey suyu olarak baraj sularında önemli bir bağımlılık olduğu, bunun dışında kuyu ve kaynak sularından su çekiminin de dikkate değer olduğu tekrar tespit edildi. Son olarak 10 büyükşehir özelinde, farklı kaynaklara göre su çekim oranları Şekil 8'de verildi. Büyük şehirlerin büyük bir çoğunluğunda içme-kullanma suyu temininde ana kaynağın barajlar olduğu gözlenebilir. Antalya, İzmir ve Konya'da ise ağırlıklı olarak kuyulardan su çekilmektedir. Bu durum coğrafi özelliklerle ilişkilidir. Antalya'da yüzey suları oranı düşük olmamasına rağmen, topografya geniş baraj alanları oluşturmak için uygun değildir. Buna karşın, karstik yapı sayesinde zengin bir yeraltı suyu rezervi vardır. Konya'da yüzey sularının kısıtlılığı, zorunlu olarak su tedariğinin yeraltı suyuna yönelmesine neden olur. Buradaki karstik yapı suyun yeraltında birikmesine olanak sağlamaktadır. İzmir'de ise yüzey sularının kirlilik yüklerinin fazlalığı ciddi bir sorundur. Ova alanlarında kuyu sularının erişilebilir olması, burada kuyu suyu çekimini öne çıarmaktadır. İstanbul için ise 2018 yılı itibariyle, evsel su tüketiminin yaklaşık \% 39,7'si akarsulardan, \% 42,8'i barajlardan, \%16,4'ü göl ve göletlerden sağlanmıştır. Bu çok yüksek oranda yüzey sularına bağımlılık anlamına gelir. Bu nedenle tek mevsimlik bir kuraklık dahi, İstanbul'da su stresine yol açabilmektedir. Çalışmanın son bölümünde, 
Türkiye'de evsel su talebinin karşılanması noktasında mevcut durum değerlendirmesinden yola çıkılarak var olan sorunlar, olası riskler ve çözüm önerileri değerlendirildi.

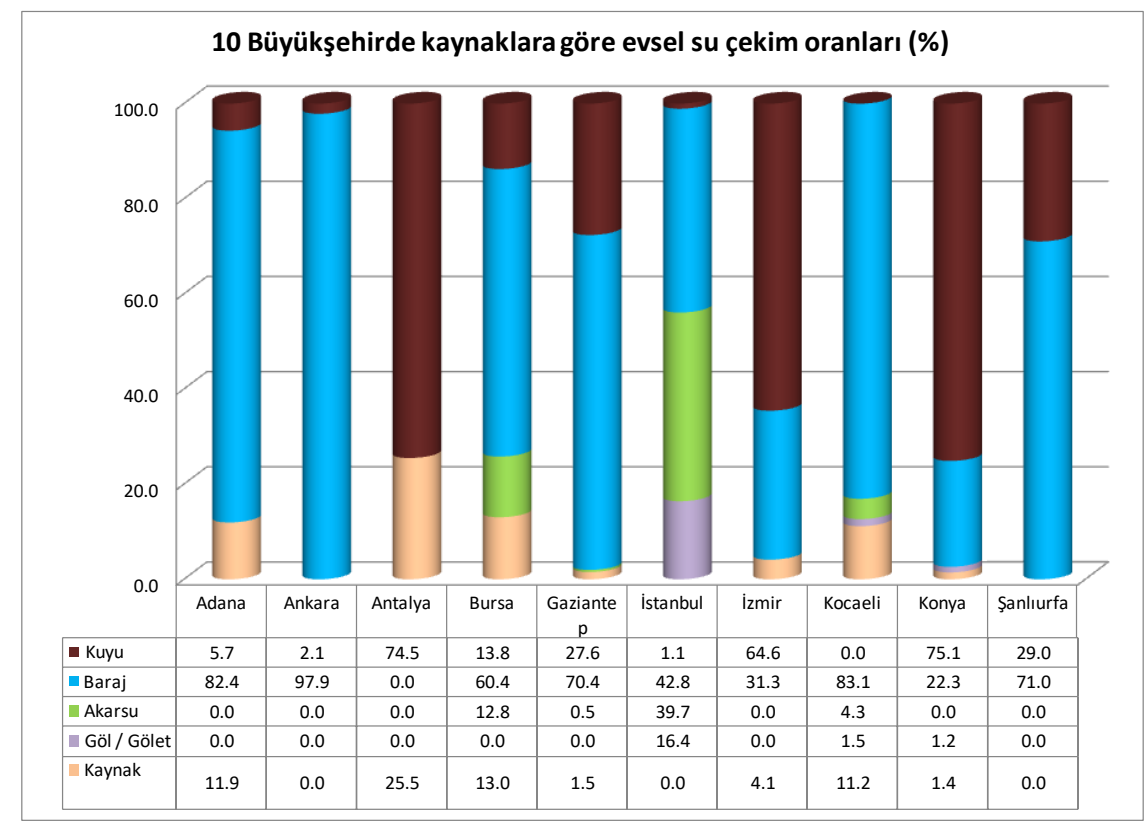

Şekil 8. 10 büyükşehirde 2018 y1lı su çekim oranları

\section{Tartışma ve Sonuç}

Türkiye için 1994-2018 yılı belediyeler düzeyinde içme-kullanma suyu zaman serileri ve 2018 y1lı özelinde il ölçeğinde alansal istatistiklerle yapılan değerlendirmeler sonucunda elde edilen bulgular aşağıdaki şekilde özetlenebilir:

- Türkiye'de evsel su kullanımı için çekilen yıllık su miktarı giderek artmaktadır ve bu artışın 2008 'den sonra hızlandığı gözlenmektedir.

- Kişi başına düşen evsel su miktarı ise 2000'li yıllardan bu yana azalış trendi sergilemektedir. Türkiye geneli için değerlendirildiğinde, bu durumun öncelikli olarak nüfus baskısı ile ilişkili olduğu ifade edilebilir.

- Yıllık su çekim miktarındaki zamansal değişimle paralel bir biçimde, yerüstü su kaynaklarından su çekimi 2008 yılından sonra yeraltı suyu oranlarını geçtiği gözlenmektedir.

- Yerüstü (yüzey) sularından su çekimi en fazla barajlardan yapılmaktadır. Akarsulardan çekim son y1llarda artış sergilemektedir.

- Su kaynaklarına bağımlılık açısından değerlendirildiğinde, kuyu (yeraltı suları) İç Anadolu ve Batı Akdeniz (Göller bölgesi); pınar Doğu Anadolu; Barajlar Marmara, İç Anadolu, Doğu Akdeniz ve GAP Bölgesi; ve akarsularda ise Karadeniz bölgesinde birkaç il ile Siirt ve İstanbul 
dikkati çeker. Göl/gölet kaynağından su çeken il sayısı çok azdır en fazla Sakarya, Isparta ve İstanbul'da görülür.

Tüm bu bulgulara bakıldığında rezervuarlardan çekilen su miktarlarının sürekli arttığı, yüzey sularından su çekiminin fazlalaştığı ve batı bölgelerde su çekiminin doğuya oranla önemli ölçüde yüksek olduğu ifade edilebilir. Subtropikal ve Orta kuşak iklimleri arasında yer alan ve doğu-batı yönünde geniş bir ülke olan Türkiye'de, kompleks topografik yapısının da etkisiyle yerel olarak farklı yağış rejimleri gözlenmektedir (Sarış vd., 2010). Yağışlardaki bu farklılaşma farklı bölge/havza veya illerde farklı su potansiyellerinin oluşmasına neden olmaktadır. Su potansiyeli açısından Doğu Anadolu, Karadeniz ve Akdeniz'in kar rejimli akarsuları önemli bir kaynak olarak öne çıkarken, kapalı havzalarda(Konya, Burdur ve Afyon gibi) yeraltı suları daha önemlidir. Kaynağı ne olursa olsun, hem iklim krizi hem de artan nüfus ve su talebi, bütün su kaynakları üzerinde baskı yaratır ve yaratacaktır.

Türkiye'de yağış değişkenliğini ele alan çalışmalara bakıldığında, batı bölgelerde yıllık yağış tutarlarında azalma gözlenmekle birlikte daha kritik olarak yağışlı gün sayısında azalma ve ani şiddetli sağanak olaylarında artış gözlenmesidir (Türkeş vd., 2009). Doğu bölgelerde yağış deseni açısından en önemli bulgular; artan sıcaklıklar birlikte hem kar yağışlı gün sayıları ve tutarındaki azalmalar, hem de kar erime sürecinin hızlanmasıdır (Özgür, 2013). Yağış rejimindeki bu değişimler, arazi örtüsü değişiklikleri ile birleşince farklı rezervuarlarda (akarsu, göl, yeraltı suyu) farklı su sorunlarına yol açar. Akarsularda debi azalması gibi etkiler daha hızlı gözlenirken, yeraltı suyunda seviye düşmesi daha uzun vadede gerçekleşir ancak etkili bir su yönetimi devreye konulmadıkça kaynakların yetersiz kalması kaçınılmazdır. Orman alanlarının yok edilmesi ile birlikte betonlaşmanın artması sonucunda yağışın toprak tarafından tutulamaması (sızmanın azalması), dolayısıyla akış katsayısının giderek arttığı ve rezervuarlarda tutulan su miktarının azaldığı bir tablo ortaya çıkar. Küresel ortalama sıcaklıklarda sanayi devriminden bu yana $1,2{ }^{\circ} \mathrm{C}$ 'lik bir artış söz konusudur. Her on yıl için artış oranı $0,2{ }^{\circ} \mathrm{C}$ olarak hesaplanmaktadır (IPCC, 2019). Artan sıcaklıklar hem açık su yüzeylerinde (göl, gölet, baraj) hem de toprak neminde buharlaşmanın artması ve su açı̆̆ 1 dönemlerinin genişlemesine neden olur. Türkiye bu açıdan riskli ülkeler arasında yer alır.

Su kanununa göre, su kullanımda doğal hayatın korunması ve içme kullanma suyu güvenliği önceliklidir (Yıldırım ve Ayanoğlu, 2014). Var olan su güvenliği riskleri karşısında içme ve kullanma suyu kaynaklarının sürdürülebilir ve etkin kullanımı için belediyelerin yenilikçi çözümler üretmeleri gerekmektedir. Kentsel su temini, evsel su dağıtım ağlarının daha iyi idare edilmesini ve işletilmesini gerektirir. Karar verme süreçleri, tüm sorunları doğru ve zamanında ele almak için; akışlar, olası arızalar, kayıplar veya diğer sorunlar gibi sistem işleyişini tanımlayan güvenilir verilere dayanmalıdır (Tzanakakis vd., 2020; Tuğaç (2018) OECD Kompakt Kent ve Avrupa Birliği (AB) Eko-kent yaklaşımlarında yer alan ölçütleri ele alarak Türkiye için bazı önerilerde bulunmuştur. AB Eko-Kent ölçütlerinden biri birincil su tüketiminin azaltılması olarak belirtilmektedir. Bunun için bütünleşik kentsel su yönetiminin benimsenmesi, kentlerde yeşil altyapı, atık su arıtımı ve atık suların yeniden kullanılması, yağmursuyu hasadı, şebekedeki kaçakların önlenmesi gibi su miktarını ve kalitesini koruyacak çalışmalar uygulanmaktadır. Özellikle su arıtma tesislerinde yenilebilir enerji kullanımıyla fosil yakıt tüketiminin de önüne geçilebilir. Türkiye'de bazı kentlerde bu tarz uygulamalar vardır. Evsel su tüketimini azaltmak ve kaynakları korumaya yönelik davranışları geliştirmek için kentlerde 
sosyolojik birtakım çalışmalarda yürütülmektedir. Koop vd. (2019) tarafindan ifade edildiği gibi, davranışsal etkileme taktikleri olarak adlandırılan bilgi aktarımı, öz yeterliliği artırma, sosyal normlar gibi pek çok taktikle bireylerin tüketim davranışlarını dönüştürmeye, tüketen değil üreten ya da türetici olmaya motive eden sosyal dayanışma çalışmaları gerçekleştirilmesi oldukça faydalı olabilir.

Su güvensizliği yani "üretken bir yaşam için yeterli ve güvenli su eksikliği" günümüzde ve öngörülebilir bir gelecekte yeryüzünün karşı karşıya olduğu en büyük tehditlerden biridir (Wutich, 2019). Su güvenliğini tehdit eden dinamikler havza ölçekli su dengesi değişikliklerine yol açan süreçler, iklim değişikliği ve değişkenliği, ormansızlaştırma, sulak alan drenajı, sulama, rezervuarlardan buharlaşma ile su kaybı, soğutma suyu kaybı ve havzalar arası su transferi olarak özetlenebilir (Vörösmarty vd., 2004). Bu süreçlere ek olarak, akarsular üzerinde birden fazla hidroelektrik santral (depolamalı veya nehir tipi) kurulması sonucunda akarsu fragmantasyonunun artması ve akarsu rekonstrüksiyonu için beton yapı malzemesi kullanılması gibi olumsuz uygulamalar da suyun doğal döngüsüne aşırı müdahale kapsamında değerlendirilmelidir. Bu durum suyun bir havzada zamansal ve alansal erişilebilirliğini, miktarını ve kalitesini olumsuz yönde etkilemektedir. Bu noktada Vörösmarty vd. (2004) de ifade ettiği gibi, küresel su sorunu ile baş edebilmek için sosyal bilimler ve doğa bilimleri arasındaki kavramsal ve pratik boşlukları kapatacak ortak bir çerçeve oluşturarak hareket etmek rasyonel olacaktır. Gelişmekte olan ülkelerde, biyoçeşitliliği korurken bir yandan insan etkinlikleri için su güvenliğini sağlamak ikili bir zorluk yaratmakta ve burada dengeyi sağlamak için en uygun çözümün entegre (bütünleşik) su kaynakları yönetimi olduğu ifade edilmektedir (Bogardi vd., 2012; Vörösmarty vd., 2010).

Türkiye açısından da tüm paydaşların katılımını gözeten, sürdürülebilirliği üç boyutuyla da (ekolojik, sosyal ve ekonomik) ele alan ve bilime dayanan bir su yönetimi yaklaşımı benimsenmelidir. Sürdürülebilirlikte esas olan ekolojik sürdürülebilirlik olmalıdır; zira kapsayıcı olan budur. Ekosistemin varlığını sürdürmesine olanak sağlayan, hidrolojik döngüyü bozmayan bir su yönetimi çerçevesinde sosyal ve ekonomik sürdürülebilirlik sağlanabilir. Bunun için tüm su kullanıcıları, politika yapıcı ve karar vericiler etkin su kullanımını mutlaka dikkate almalıdır; çünkü su kaynakları sınırsız değildir. Suyun yağışlarla yenilenebilmesi için orman varlığı korunmalıdır. Ekolojik perspektiften ve bütüncül bir bakış açısı ile, başta içme ve kullanma suyu olmak üzere insan etkinlikleri için gerekli su talebi güvence altına alınabilir.

\section{Teşekkür ve Bilgilendirme}

Haritaların düzenlenmesinde katkılarından dolayı Furkan Gedik'e teşekkür ederim. 


\begin{tabular}{ccc} 
Coğrafi Bilimler Dergisi & Cografi \\
Bilimler & Dergisi \\
\hline
\end{tabular}

\title{
Evaluation of Domestic Water Supply and Use Statistics of Turkey
}

\author{
Faize Sarış*a
}

\section{EXTENDED ABSTRACT}

\section{Introduction}

The world population, which was 6.1 billion in the early 2000s, has now approached 7.7 billion (World Bank Statistics, 2020). This rapid population growth has brought many challenges such as meeting the water, food and energy demand. According to the 2020 report of the World Water Assessment Program, water stress defined as the insecurity of the water supply distresses every continent to a certain extent; half of the world's population experiences water scarcity for at least one month in a year (WWDR, 2020). Water scarcity means physical shortage or access scarcity due to institutions not providing regular water services due to lack of water or inadequate infrastructure. Fresh water scarcity directly affects food security, access to safe drinking water, hygiene and public health and environmental well-being (Taylor, 2009).

Rapid and often unplanned urban growth, which is associated with poverty, strains environmental service capacities such as drinking water supply and treatment, sanitation, and waste disposal. Such urbanization processes often result in significant over demand and excessive use of water for domestic purposes (Moorea et al., 2003).

These challenges are also observed in Turkey where economic growth targets put pressures on water resources. Currently, the potential surface water in Turkey that can be consumed for various purposes is 94 billion $\mathrm{m}^{3}$ per year, while the groundwater potential determined as 18 billion $\mathrm{m}^{3}$. The 57 billion $\mathrm{m}^{3}$ is available water which $77 \%$ of this amount is utilised in agriculture and $23 \%$ is consumed as domestic and industrial water (DSİ, 2020). The amount of water available per capita/year is $1346 \mathrm{~m}^{3}$ in Turkey, which places the country among the regions experiencing water stress.

This study provides an assessment on the water security issues of Turkey in terms of domestic water perspective. The literature review has shown the lack of a detailed spatial and temporal analysis based on water statistics. Considering this research gap; this study aimed to discuss the status of domestic water consumption for Turkey by evaluating the temporal change of drinking water supply and consumption status, explaining the spatial variations in drinking water supply and consumption with

\footnotetext{
*Corresponding Author: faizesaris@ gmail.com

${ }^{a}$ Çanakkale Onsekiz Mart University, Faculty of Arts and Sciences, Çanakkale, Turkey. http://orcid.org/xxxx-0002-17214959)
} 
their physical and social reasons, revealing the pressures on surface and groundwater resources and highlighting hot spots.

\section{Methodology}

Domestic water statistics were provided by the Turkish Statistical Institute (TUIK, 2020). The data evaluated within the scope of the study are listed below:

Country statistics used for temporal and spatial evaluation:

1. Rate of municipal population served by water supply network in total municipal population $(\%)$

2. Total amount of water abstracted for drinking and utility water network (thousand $\mathrm{m}^{3} / \mathrm{year}$ )

3. Amount of water abstracted according to the source: Spring (thousand $\mathrm{m}^{3}$ ), lake/pond/sea (thousand $\mathrm{m}^{3}$ ), river (thousand $\mathrm{m}^{3}$ ), dam (thousand $\mathrm{m}^{3}$ ), well (thousand $\mathrm{m}^{3}$ )

4. The amount of surface water abstracted for domestic water network (thousand $\mathrm{m}^{3} / \mathrm{year}$ )

5. The amount of groundwater abstracted for domestic water network (thousand $\mathrm{m}^{3} /$ year)

6. Average amount of water abstraction per capita (liter/person/day)

Water statistics were examined through graphics and maps. Temporal and spatial variations were interpreted considering various dynamics and previous studies.

\section{Result}

Although the amount of water withdrawn for domestic water has doubled in 25 years; there is a noteworthy decrease in the daily amount of water abstracted per capita. Similarly, Turkey's population showed a significant increase in the last 25 years, reaching nearly 80 million from 60 million; hence water demand has increased in all sectors to meet the needs of this growing population. Both surface and groundwater resources in Turkey has been used extensively in the last 25 years. Surface water utility (dam, lake/pond and stream) has increased since 2008, while wells and springs were used mainly for domestic water withdrawal until 2008 throughout the country. One of the most important reasons for this situation is the ascending dam projects since the 2000s. In parallel with the increasing population and urbanization rate, water withdrawal from dams increased significantly.

The provincial-based assessment shows that the highest total water withdrawal occurred in 3 metropolitan cities namely Istanbul, Ankara and Izmir. Although the amount of water abstracted per capita in 2018 is generally higher in the east and southeast (Ardahan, Kars, Erzurum, Muş, Bitlis, Batman, Malatya and Kahramanmaraş). In addition, very high amounts were recorded at Trabzon in the Black Sea region, Balıkesir in the Marmara region in the west, Sakarya and Yalova in the west, and at Muğla and Antalya in the Mediterranean region. In the eastern provinces, the population is low and water resources are abundant. The high amounts observed in the other provinces distributed to the west and south can be related to the richness of primarily groundwater resources. The areas with the lowest average daily water withdrawal per capita are regionally located in the Marmara region. Although the Marmara region is the most densely populated region of the country, it is not rich in water resources and the amount of water withdrawn per capita is gradually decreasing. Except for the Marmara region, the average daily water withdrawal per capita is low in some provinces in Central and Southeastern Anatolia regions. 
When evaluated in terms of dependency on water resources; well (groundwater) is the most utilised resource in Central Anatolia and Western Mediterranean (Lakes region); springs are important for Eastern Anatolia; while dams are widely used in Marmara, Central Anatolia, Eastern Mediterranean and Southeastern Anatolia regions. For utilising rivers, Siirt and Istanbul attract attention with a few provinces in the Black Sea region. The number of provinces that water abstraction from the freshwater lakes is very few, but it is mostly seen in Sakarya, Isparta and Istanbul. This spatial pattern is highly associated with geological/geomorphological and climatological characteristics of Turkey.

\section{Discussion}

These findings indicate that the amount of water withdrawn from the reservoirs is constantly increasing, surface water abstraction is growing and the water withdrawal is significantly higher in the western regions compared to the east. Turkey is a large country extending between subtropical and midlatitude climate zones and with the effect of its complex topography different precipitation regimes are locally observed (Sarış et al. 2010). This differentiation in precipitation causes different water potentials in different regions / basins or provinces. While the nival rivers of Eastern Anatolia, Black Sea and Eastern Mediterranean regions stand out as an important resource in terms of water potential; groundwater is more important in closed basins (such as Konya, Burdur and Afyon). Both the climate crisis and the increasing population and water demand will put pressure on all water resources.

In the western regions of the country, the annual precipitation amount and the number of rainy days have been decreasing (Türkeş et al., 2009); whereas the number of snowy days and amount of snowfall have been descending in the eastern regions (Özgür, 2013). These changes in the precipitation regime, combined with the land cover changes cause various water problems in different reservoirs (streams, lakes, groundwater). While impacts such as the decrease in river flows are observed more rapidly, the level decrease in groundwater takes place in a longer term, but it is inevitable that resources will be insufficient unless an effective water management is put into practice. Deforestation and construction spreading over upper basins restrict the infiltration capacity of the soil, thus a picture emerges that the flow coefficient gradually increases and the amount of water held in reservoirs decreases. There has been an increase of $1.2^{\circ} \mathrm{C}$ in global average temperatures since the industrial revolution. The rate of increase for each decade is calculated as $0.2{ }^{\circ} \mathrm{C}$ (IPCC, 2019). Increasing temperatures cause increased evaporation and widening of water deficit periods both on open water surfaces (lake, pond, dam) and soil moisture. Turkey is among the countries at risk in terms of strengthened drying conditions.

\section{Conclusions}

- The annual amount of water withdrawn for domestic water usage in Turkey is increasing and it is observed that this increase has accelerated after 2008.

- The amount of domestic water per capita has been on a decreasing trend since the 2000s which can be explained by population pressure.

- In parallel with the temporal change in the annual water withdrawal amount, it is observed that the water withdrawal from surface water resources exceeded the groundwater rates after 2008. 
- Water withdrawal from surface waters is mostly made from dams. Withdrawal from rivers has increased in recent years.

Water insecurity is one of the biggest threats facing the earth today and in the foreseeable future (Wutich, 2019). Dynamics that threaten water security can be summarized as processes that lead to basin-scale water balance changes, climate change and variability, deforestation, wetland drainage, irrigation, evaporation from reservoirs, loss of cooling water, and water transfer between basins. In developing countries, maintaining human water security while protecting biodiversity creates a dual challenge, and here it is stated that the most appropriate solution to achieve balance is integrated water resources management (Bogardi et al.2012; Vörösmarty et al.2010).

In Turkey; a water management approach based on science should be adopted, which takes into account the participation of all stakeholders, addresses sustainability in all three dimensions (ecological, social and economic). Social and economic sustainability can be achieved within the framework of water management that allows the ecosystem to survive and does not disrupt the hydrological cycle. For this, all water users, policy makers and decision makers must take into account the effective water use, because water resources are not unlimited. The efficiency of water replenishment is related to the conservation of forests. With an ecological and holistic perspective, the water demand for human activities especially drinking and utility water can be secured.

\section{Referanslar/References}

Arnell, N. (1999). Climate change and global water resources. Global Environmental Change, 9, 31-49. doi: 10.1016/S09593780(99)00017-5

Aküzüm, T., Çakmak, B., Gökalp, Z., Yazar, S. (2010). Türkiye'de su kaynaklari yönetiminin değerlendirilmesi. Tarım Bilimleri Araştırma Dergisi, 3 (1), 67-74. https://dergipark.org.tr/tr/download/article-file/412800 adresinden alındı.

Alcamo, J., Döll, P., Henrichs, T., Kaspar, F., Lehner, B., Rösch, T., Stefan Siebert, S. (2003). Global estimates of water withdrawals and availability under current and future "business-as-usual" conditions. Hydrological Sciences Journal, 48 (3), 339-348. doi: 10.1623/hysj.48.3.339.45278

Alcamo, J., Flörke, M., Märker, M. (2007). Future long-term changes in global water resources driven by socio-economic and climatic changes. Hydrological Sciences Journal, 52 (2), 247-275. doi: 10.1623/hysj.52.2.247

Bogardi, J., Dudgeon, D., Lawford, R., Flinkerbusch, E., Meyn, A., Pahl-Wostl, C., Vielhauer, K., Vörösmarty, C. (2012). Water security for a planet under pressure: interconnected challenges of a changing world call for sustainable solutions. Current Opinion in Environmental Sustainability, 4, 35-43. doi: 10.1016/j.cosust.2011.12.002

Bulut, M., Birben, Ü. (2019). AB su çerçeve direktifinin türkiye'de su kaynakları yönetimine etkisi. Türkiye Ormancılık Dergisi, 20, 221-233. doi: 10.18182/tjf.562550

Cook, C., Bakker, K. (2012). Water security: Debating an emerging paradigm. Global Environmental Change, 22 (1), 94-102. doi: 10.1016/j.gloenvcha.2011.10.011

Cook, C. (2016). Implementing drinking water security: the limits of source protection. Wiley Interdisciplinary Reviews: Water, 3, 5-12. doi: $10.1002 /$ wat 2.1117

Delpla, I., Jung, A.V., Baures, E., Clement, M., Thomas, O. (2009). Impacts of climate change on surface water quality in relation to drinking water production. Environment International, 35 (8), 1225-1233. doi: 10.1016/j.envint.2009.07.001

Devlet Su İşleri Su istatistikleri (DSİ, 2019). 12/01/2021 tarihinde https://www.dsi.gov.tr/Sayfa/Detay/1344 adresinden alınd1.

Devlet Su İşleri Toprak Su Kaynakları (DSİ, 2020). 12/01/2021 tarihinde https://www.dsi.gov.tr/Sayfa/Detay/754 adresinden alınd.

Devlet Su İşleri Faaliyet raporu (DSİ, 2020). 05/02/2021 tarihinde https://www.dsi.gov.tr/Sayfa/Detay/759 adresinden alındı.

Erol, A. ( 2006). Su Kaynaklarının Korunmasında Havza Yönetimi İlkelerinin Önemi. TMMOB Su Politikaları Kongresi. 
Falkenmark, M., Widstrand, C. (1992). Population and Water Resources: A Delicate Balance. Population Bulletin, Population Reference Bureau.

Food and Agriculture Organization (FAO, 2008). 12/01/2021 tarihinde http://www.fao.org/aquastat/en/countries-andbasins/country-profiles/country/TUR adresinden alındi.

García-Ruiz, J.M., López-Moreno, J., Vicente-Serrano, S., Martínez, T., Beguería, S. (2011). Mediterranean water resources in a global change scenario. Earth-Science Reviews, 105, 121-139. doi: 10.1016/j.earscirev.2011.01.006

Garipağaoğlu, N. (2012). Havza planlamalarında coğrafyanın rolü ve Türkiye'de havza planlamacıllğı. Atatürk Üniversitesi Sosyal Bilimler Enstitüsü Dergisi, 16 (2), 303-336. https://dergipark.org.tr/tr/pub/ataunisosbil/issue/2830/38438 adresinden alınd.

Hope, R., Rouse, M. (2013). Risks and responses to universal drinking water security. Philosophical Transactions of Royal Society A, 371, 1-22. doi: 10.1098/rsta.2012.0417

Intergovernmental Panel on Climate Change (IPCC, 2019). 24/1/2020 tarihinde https://www.ipcc.ch/site/assets/uploads/sites/2/2019/06/SR15_Full_Report_High_Res.pdf adresinden alınd1.

Karaman, S., Gökalp, Z. (2010). Küresel ısınma ve iklim değişikliğinin su kaynakları üzerine etkileri. Tarım Bilimleri Araştırma Dergisi, 3 (1): 59-66. https://dergipark.org.tr/tr/download/article-file/412801 adresinden alınd1.

Kanber, R., Baştuğ, R., Büyüktas, D., Ünlü, M., Kapur, B. (2010). Küresel İklim Değişikliğinin Su Kaynakları ve Tarımsal Sulamaya Etkileri, Türkiye Ziraat Mühendisliği VII. Teknik Kongresi, Bildiri Kitabı içinde (83-118).

Kılıç, S. (2011). Küresel iklim değişikliği sürecinde su yönetimi. I.Ü. Siyasal Bilgiler Fakültesi Dergisi, 39, 161-186. https://dergipark.org.tr/tr/download/article-file/5315 adresinden alınd.

Koop, S., Dorssen, A.J., Brouwer, S. (2019). Enhancing domestic water conservation behaviour: A review of empirical studies on influencing tactics. Journal of environmental management, 247, 867-876. doi: 10.1016/j.jenvman.2019.06.126

Meriç, T. (2004). Su kaynakları yönetimi ve Türkiye. Jeoloji Mühendisligi Dergisi, 28 (1), 27-38. https://www.jmo.org.tr/resimler/ekler/139aeda1c2914e3_ek.pdf adresinden alınd1.

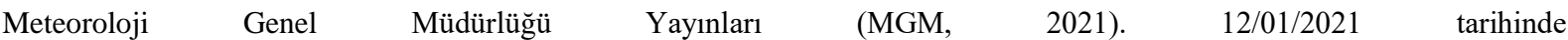
https://www.mgm.gov.tr/FILES/genel/makale/2013-2014kuraklikanalizi.pdf adresinden alınd1.

Moore, M., Gould, P., Keary, B. S. (2003). Global urbanization and impact on health. International Journal of Hygiene and Environmental Health, 206 (4-5), 269-278. doi: 10.1078/1438-4639-00223

Özgür, E. (2013). Kar Yağışlı Gün Sayılarının Toplam Yağış̧ı Gün Sayılarına Oranının Yıllık Ve Bölgesel Trend Analizi. İTÜ Fen Bilimleri Enstitüsü, Yayınlanmamış Yüksek Lisans Tezi, İstanbul. https://tez.yok.gov.tr/UlusalTezMerkezi/332971 adresinden edinilmiştir.

Öztürk, S., Ubay Tönük, G., Gülgün, B. (2014). Türkiye'de havza yönetimi ve yönetim planı yaklaşımları. Ziraat Mühendisliği Dergisi, 361, 59-63. https://dergipark.org.tr/tr/download/article-file/946528 adresinden alındı.

Sarış, F., Hannah, D., Eastwood, W. (2010). Spatial variability of precipitation regimes over Turkey. Hydrological Sciences Journal, 55, 234 - 249. doi: 10.1080/02626660903546142

Schlosser, C. A., Strzepek, K., Gao, X., Fant, C., Blanc, É., Paltsev, S., Jacoby, H., Reilly, J., Gueneau A. (2014). The future of global water stress: An integrated assessment. Earth's Future, 2, 341-361. doi:10.1002/2014EF000238

Sullivan, C.A., Meigh, J.R., Giacomello, A.M., Fediw, T., Lawrence, P., Samad, M., Mlote, S., Hutton, C., Allan, J.A., Schulze, R.E., Dlamini, D.J.M., Cosgrove, W., Delli Priscoli, J., Gleick, P., Smout, I., Cobbing, J., Calow, R., Hunt, C., Hussain, A., Acreman, M.C., King, J., Malomo, S., Tate, E.L., O’Regan, D., Milner S., Steyl, I. (2003). The Water Poverty Index: Development and application at the community scale. Natural Resources Forum, 27, 189-199. doi: $10.1111 / 1477-8947.00054$

Şen, Z. (2005). İklim Değişikliği ve Su Kaynaklarına Etkisi. 22 Mart Dünya Su Günü İklim Değişikliğinin Su ve Enerji Kaynaklarımıza Etkisi Paneli 22 Mart 2005, Bildiriler Kitabı içinde.

Taylor, R. (2009). Rethinking water scarcity: The role of storage. Eos, Transactions,AGU, 90 (28), 237-248. doi: $10.1029 / 2009 \mathrm{EO} 280001$

Tuğaç, Ç. (2014). İklim güvenliği kapsamında su kaynaklarının yönetimi. TODAİE Çağdaş Yerel Yönetimler Dergisi, 23(3), 1-30. https://cyy.hacibayram.edu.tr/Dergiler adresinden alınd1.

Tuğaç, Ç. (2018). Türkiye için iklim değişikliğine dayanıklı kentsel planlama modeli önerisi: Eko-kompakt kentler. Atatürk Üniversitesi İktisadi ve İdari Bilimler Dergisi, 32(4), 1047-1068. https://dergipark.org.tr/tr/download/articlefile/548375 adresinden alınd. 
Türkeş, M., Koç, T., Sarış, F. (2009). Spatiotemporal variability of precipitation total series over Turkey. International Journal of Climatology, 29, 1056-1074. doi: 10.1002/joc.1768

Türkiye İstatistik Kurumu (TUIK, 2020). 10/12/2020 tarihinde https://data.tuik.gov.tr/Kategori/GetKategori?p=Cevre-veEnerji-103 adresinden alınd.

Tzanakakis, V.A., Paranychianakis, N., Angelakis, A. (2020). Water supply and water scarcity. Water, 12 (2347), 1-16. doi:10.3390/w12092347

United Nations Environment Programme (UNEP, 2004). Global Environment Outlook Scenario Framework. Background Paper for UNEP's Third Global Environment Outlook Report (GEO-3). 18/12/2020 tarihinde https://wedocs.unep.org/handle/20.500.11822/8521 adresinden alınd1.

Vörösmarty, C., Lettenmaier, D., Lévêque, C., Meybeck, M., Pahl-Wostl, C., Alcamo, J., Cosgrove, W., Grassl, H., Hoff, H., Kabat, P., Lansigan, F., Lawford, R., Naiman, R. (2004). Humans transforming the global water system. Eos, Transactions American Geophysical Union, 85, 509-514. doi: 10.1029/2004EO480001

Vörösmarty, C., McIntyre, P., Gessner, M., Dudgeon, D., Prusevich, A., Green, P., Glidden, S., Bunn, S., Sullivan, C., Liermann, C.R., Davies, P. (2010). Global threats to human water security and river biodiversity. Nature, 467, 555561. doi:10.1038/nature09440

World Bank Statistics (WB, 2020). 18/12/2020 tarihinde https://data.worldbank.org/indicator/SP.POP.TOTL adresinden alındı.

World Water Development Report (WWDR, 2020: https://unesdoc.unesco.org/ark:/48223/pf0000372985.locale=en adresinden alındi.

Wutich, A. (2019). Water insecurity: An agenda for research and call to action for human biology. American Journal of Human Biology, 32 (1). doi: 10.1002/ajhb.23345

Yıldırım, H., Ayanoğlu, S. (2014). Su kanunu tasarısının hukuksal değerlendirilmesi. Journal of the Faculty of Forestry Istanbul University, 64, 29-37. doi: 10.17099/jffiu.96234 